\title{
Intramedullary Nailing for Paediatric Diaphyseal Forearm Bone Fracture
}

\author{
Parajuli NP, Shrestha D, Dhoju D, Dhakal GR, Shrestha R, Sharma V.
}

Department of Orthopaedics and Traumatology

Dhulikhel Hospital - Kathmandu University Hospital

Dhulikhel, Nepal

Corresponding Author

Nirajan Prasad Parajuli

Department of Orthopedics and Traumatology

Kathmandu University Hospital

Dhulikhel, Kavre

Email: parajulinirajan@gmail.com

Citation

Parajuli NP, Shrestha D, Dhoju D, Dhakal GR, Shrestha $R$, Sharma V. Intramedullary nailing for paediatric diaphyseal forearm bone fracture. Kathmandu Univ Med J. 2011;35(3):198-202.

\begin{abstract}
Background

Though most of the pediatric diaphyseal forearm bone fracture can be treated with closed reduction and cast application, indications for operative intervention in pediatric both-bone forearm fractures include open fractures, irreducible fractures, and unstable fractures. Controversy exists as to what amount of angulation, displacement, and rotation constitutes an acceptable reduction.
\end{abstract}

\section{Objective}

To review union time and functional outcome of pediatric diaphyseal forearm bone fracture managed with intramedullary rush pin by closed or open reduction.

\section{Methods}

Fifty patients with both bone fracture of forearm were treated with intramedullary rush pin by closed or open reduction were included in the study and followed up for minimum six months for radilological and functional outcome.

\section{Results}

Out of 50 patients, 31 underwent closed reduction and 19 underwent open reduction. All fractures maintained good alignment post operatively. Forty seven patients had excellent results with normal elbow range of motion and normal forearm rotation and three patients had good results. In all patients good radiological union was seen in three months time. Eight patients had minor complications including skin irritation over prominent hardware, backing out of ulnar pin, superficial skin break down with exposed hardware. Twenty-three (46\%) patients had undergone implant removal at an average of 6 months (range 4-8 months) under regional or general anesthesia

\section{Conclusion}

Fixation with intramedullary rush pin for forearm fracture is an effective, simple, cheap, and convenient way for treatment in pediatric age group.

\section{KEY WORDS \\ pediatric forearm fracture, rush pin}

\section{INTRODUCTION}

Forearm fractures are common injuries in children which account for $45 \%$ of all fractures in childhood and $62 \%$ of upper limb fractures. Approximately, 75 to $84 \%$ of forearm fractures occur in the distal third, 15 to $18 \%$ occur in the middle third and 1 to $7 \%$ occurs in the proximal third of the forearm. ${ }^{1}$ Though most of those fractures can be treated successfully by close methods and cast application with satisfactory results with displaced forearm, a recognized failure rate has been reported up to $7 \%-32 \%$ and some of the indications for operative intervention are open fractures, irreducible fractures, unstable fractures, pathological fractures, fractures with neurovascular compromise, malunions, and refractures. ${ }^{2,3}$ A recent observational study showed an increase in the rate of intramedullary nailing of forearm shaft fracture from $1.8 \%$ to $22 \%$ as an alternative to cast treatment over a 10 year period. ${ }^{4}$ Shoemaker et al suggested that the ideal mode of fixation of pediatric forearm fractures should maintain alignment, be minimally invasive and inexpensive, and carry an acceptable risk profile. $^{2}$ Titanium elastic nails are icreasingly used for 


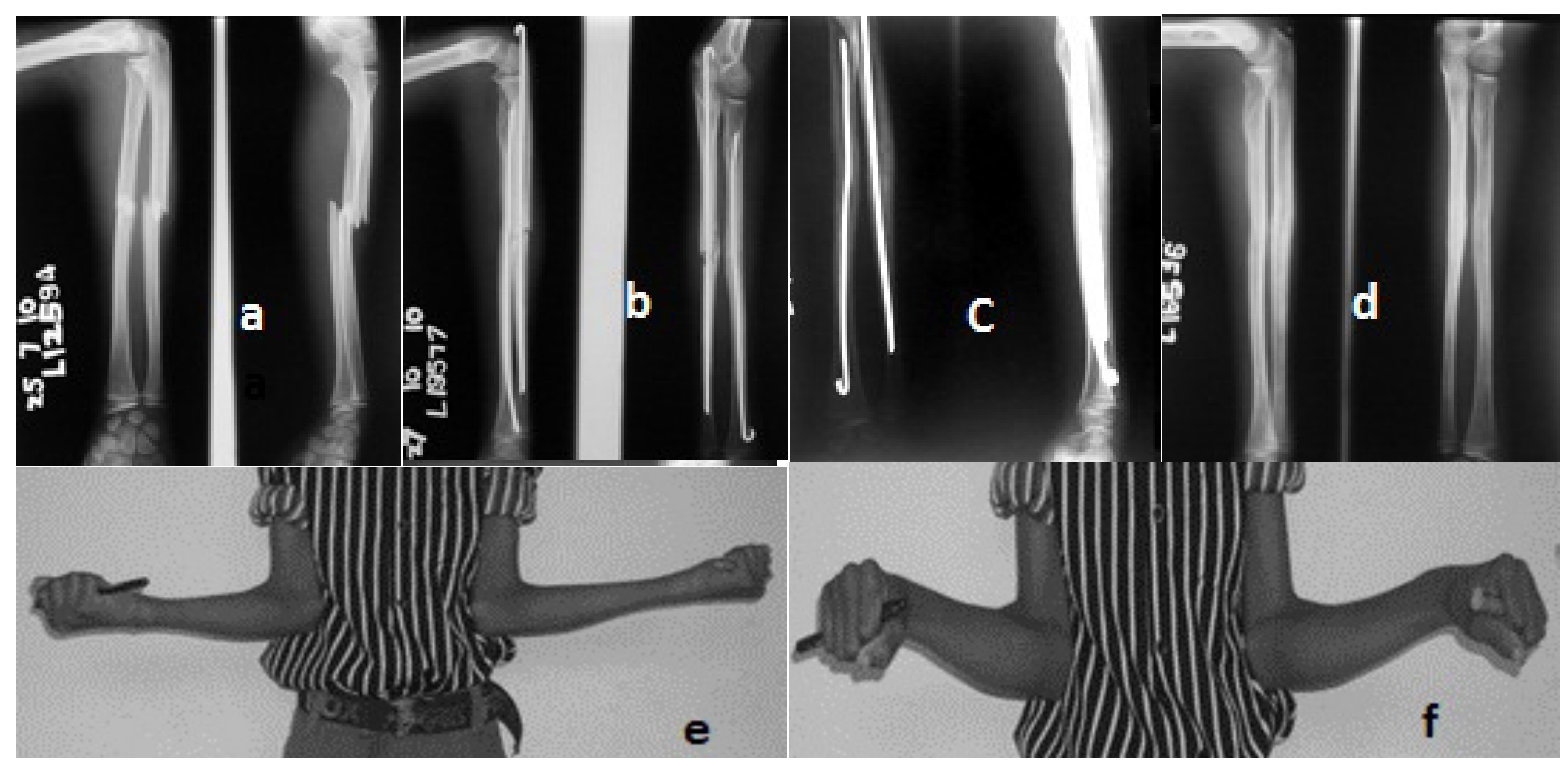

Figure 1. Pre-fixation (a), post fixation (3 months) with ulnar delayed union (b), post fixation with good union (7 months) with good function $(d, e, f)$.
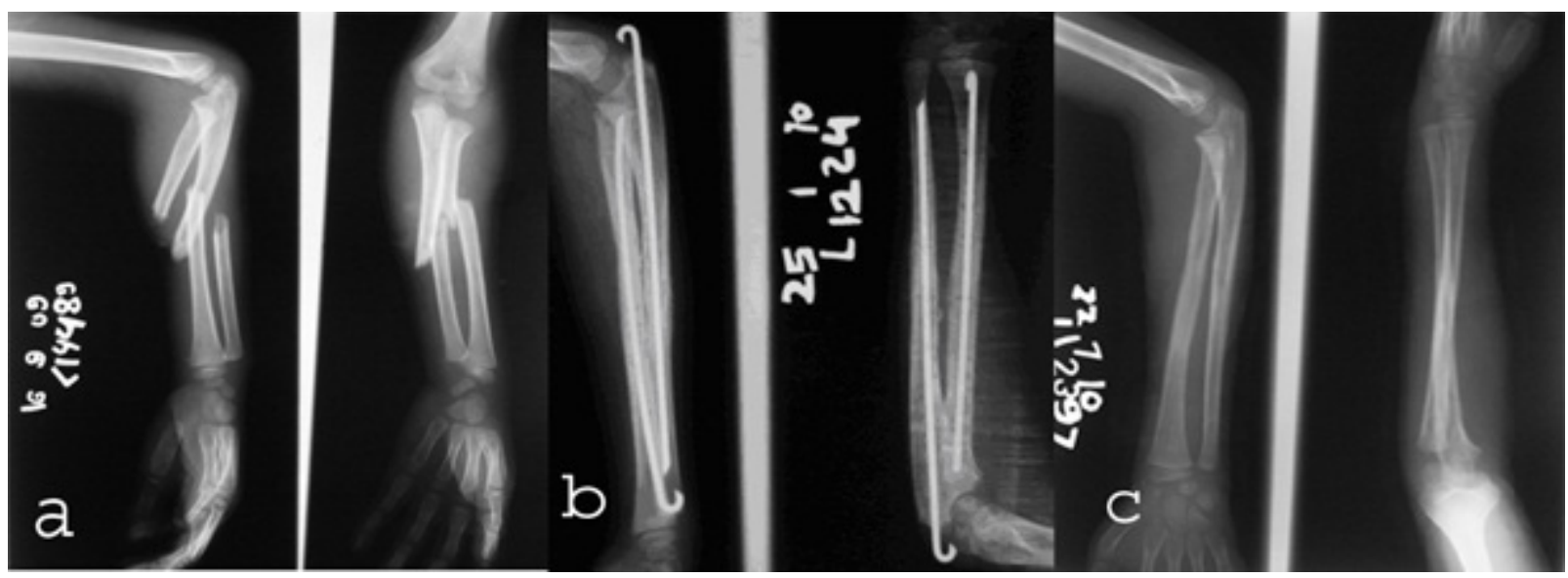

Figure 2. Prefixation (a), 4 months post fixation (b) and removal of Rush pin on 10 months(c).

intreamedullary nailing but they are expensive for most of the patients in developing countries and hence the current study is intended to review retrospectively the clinical, radiological and functional outcome of pediatric diaphyseal forearm bone fracture treated with intramedullary stainless steel Rush pins as an alternative of titanium elastic nails.

\section{METHODS}

Among 631 children who attended for forearm diaphyseal fracture in beetween Feb 2008 to Jan 2011 in Kathmandu University Hospital, Dhulikhel, 72 children were treated with intramedullary rush pin. Fifty patients were included in the present study with inclusion criterias of age $<15$ yrs, displaced fracture or grossly rotated fractures, refractures, failed close manipulation and patients with minimum follow up six months. Patients with isolated forarm bone fracture, compound fractures or fracture with neurovascualr injury were excluded.

Demographics data of patient, mechanism of injury, fracture type, fixation method, and indications for surgery were recorded. Complication rates, time for fracture union and final range of motion were evaluated in susequent follow up. Radiographic union was defined as bridging callus on anteroposterior (AP) and lateral radiographs. Clinical results were evaluated according to scale developed by Price criteria according to which results were considered excellent if no complaints with strenuous physical activity or a loss of pro-supination of $<10^{\circ}$; good if mild complaints with strenuous activity and/or $11^{\circ}-30^{\circ}$ loss of forearm rotation; fair if subjective complaints during daily activities or $31^{\circ}-90^{\circ}$ loss of forearm rotation and all other results were considered poor. ${ }^{2}$

\section{Operative Technique}

Following close reduction under general anesthesia with image intensifier control radial fracture was fixed retrogradely with a rush pin advanced through a drill hole just proximal to the distal radial epiphysis. Optimal care was taken not to injure extensor tendons and superficial radial cutaneous nerve. Ulnar fracture was fixed with a rush pin which was antegradely inserted through olecranon. The tip of the radial pin was bent to about 15 to 30 degrees for easy passage of the pin through the medullary cavity. Length of nail was measured from proximal to distal epiphysis under 
Table 1. Comparison of literature for similar studies.

\begin{tabular}{|c|c|c|c|c|c|c|c|c|c|}
\hline & $\begin{array}{l}\text { Study } \\
\text { period } \\
\text { (Years) }\end{array}$ & $\begin{array}{l}\text { Total } \\
\text { patients } \\
\text { (n) }\end{array}$ & Sex & $\begin{array}{l}\text { Mean } \\
\text { age of } \\
\text { fixation } \\
\text { (years) }\end{array}$ & $\begin{array}{l}\text { Type of Im- } \\
\text { plant Used }\end{array}$ & $\begin{array}{l}\text { Average } \\
\text { time to } \\
\text { Radiologi- } \\
\text { cal union }\end{array}$ & $\begin{array}{l}\text { Functional out- } \\
\text { come assessment } \\
\text { criteria }\end{array}$ & $\begin{array}{l}\text { Functional } \\
\text { outcome }\end{array}$ & Complication \\
\hline $\begin{array}{l}\text { Yalcinkaya M } \\
\text { et. al }{ }^{13}\end{array}$ & 8 yrs & 45 & $\begin{array}{l}M=35 \\
F=10\end{array}$ & 10 & $\begin{array}{l}\text { Rush pins, } \\
\text { Kirschner wire }\end{array}$ & $6-10$ weeks & Price criteria & $\begin{array}{l}\text { Excellent }=82.2 \% \\
\text { Good }=17.8 \%\end{array}$ & $\begin{array}{l}\text { Major }=2(4.44 \%) \\
\text { Minor }=15 \\
(33.3 \%)\end{array}$ \\
\hline Flynn JM et $\mathrm{al}^{3}$ & 11 yrs & 103 & $\begin{array}{l}\text { Not men- } \\
\text { tioned }\end{array}$ & 10.6 & $\begin{array}{l}\text { Titanium nails, } \\
\text { Kirschner wire }\end{array}$ & $\begin{array}{l}6.9-8.6 \\
\text { weeks }\end{array}$ & $\begin{array}{l}\text { Children hospital } \\
\text { of Pheladelphia } \\
\text { forearm fracture } \\
\text { fixation outcome } \\
\text { classification }\end{array}$ & $\begin{array}{l}\text { Excellent }=77.7 \% \\
\text { Fair }=14.6 \% \\
\text { Poor }=7.8 \%\end{array}$ & $\begin{array}{l}\text { Major }=4(3.8 \%) \\
\text { Minor }= \\
11(10.6 \%)\end{array}$ \\
\hline Richter D et $\mathrm{al}^{8}$ & 2 yrs & 30 & $\begin{array}{l}M=18 \\
F=12\end{array}$ & $\begin{array}{l}\text { Not } \\
\text { men- } \\
\text { tioned }\end{array}$ & Titanium Nails & 13 weeks & Tscherne score & $\begin{array}{l}\text { Excellent }=80 \% \\
\text { Good }=16.6 \% \\
\text { Fair }=3.3 \%\end{array}$ & Minor $=4(13.3 \%)$ \\
\hline $\begin{array}{l}\text { Shoemaker SD } \\
\text { et } \mathrm{al}^{2}\end{array}$ & 8 yrs & 32 & $\begin{array}{l}M=22 \\
F=10\end{array}$ & 8.8 & Kirschner wire & 12 weeks & Price criteria & $\begin{array}{l}\text { Excellent }=96.8 \% \\
\text { Good }=3.2 \%\end{array}$ & $\begin{array}{l}\text { Major }=2(6.2 \%) \\
\text { Minor }=7(21.8 \%)\end{array}$ \\
\hline Our study & 3 yrs & 50 & $\begin{array}{l}M=38 \\
F=12\end{array}$ & 10.4 & Rush pins & 8 weeks & Price criteria & $\begin{array}{l}\text { Excellent }=94 \% \\
\text { Good }=6 \%\end{array}$ & Minor= $8(16 \%)$ \\
\hline
\end{tabular}

image intensifier and the diameter of rush pin varied from 2-3 mm depending upon the diameter of size of medullary cavity at the level of isthumus. The curved ends were buried under the skin in all cases.

Post operatively, a long arm splint was used in all cases for six weeks. Physiotherapy was started as early as possible. Intermittent extension and flexion of elbow and wrist was allowed from second post operative day. Supination and pronation was allowed only after six weeks. Patients were followed up at 15 days, six weeks, three months, and six months time for clinical radiological evaluation of union and functional outcome

Data were analyzed using Statistical Package for Social Sciences (SPSS version 15 , Chicago, Illinois).

\section{RESULTS}

There were 50 patients ( 38 males and 12 females) of age three to 15 years with mean age of $10.4 \pm 3.09$ yrs, treated for diaphyseal forearm fracture with intramedullary rush pin. Twenty eight (56\%) patients had right forearm fracture and 22 (44\%) had left forearm fracture.

Among 50 children, 31 (62\%) children were managed with close manipulation and rush pin fixation. Open reduction was required in 19 (38\%) patients because of difficult cannulation due to soft tissue interposition in 17 (89\%) cases and due to presence of callus in the medullary canal in two $(11 \%)$ cases of refracture.

Patients were followed up for mean duration of 11.08 months (range 6-16 months). The average time to fracture union which is defined as presence of bridging callus on $\mathrm{AP}$ and lateral radiographs was two months (range 1.5 3 months). Outcomes according to Price criteria were excellent in 47 (94\%) patients and good in three (6\%) patients. Among patients with good outcome, one patient had restriction of $10^{\circ}$ of supination and $15^{\circ}$ of pronation and two patients restriction of $15^{\circ}$ of pronation at last follow-up. No cases of nonunions or malunions reported.

Out of the 50 patients, eight (16\%) patients had minor complications; skin irritation over prominent ulnar hardware in four, backing out of ulnar pin requiring early removal in one, superficial skin break down with exposed hardware requiring hard ware removal and antibiotics in three cases. One patient of 12 years (Fig 1) who required open reduction for ulnar fracture due to soft tissue interposition had delayed union of ulna that got united in seven months time with excellent outcome. Complications such as limb length discrepancy affecting the extremity functions, epiphyseal damage, angular or rotational deformity, synostosis or restricted elbow movement were not encountered.

Twenty-three (46\%) patients had undergone implant removal at an average of six months (range 4 - 8 months) under regional or general anesthesia (Fig 2)

\section{DISCUSSION}

Most of the pediatric forearm fractures can be managed nonoperatively by closed reduction and casting. ${ }^{1-3,5,6}$ Midshaft diaphyseal fractures and those that are proximal do not remodel as predictably; therefore, these require a more anatomic reduction. ${ }^{6}$ Controversy exists as to what amount of angulation, displacement, and rotation constitutes an acceptable reduction. Younger patients can tolerate more deformity than older children. . $^{1,4,5,7}$

Several authors have suggested that a reduction is unacceptable if the patient has an angular deformity $>10^{\circ}$ or complete displacement. ${ }^{2,3}$ Parameters for accepting rotational malalignment range from $30^{\circ}-45^{\circ}$ to none and 
some authors have noted that rotational remodeling is not predictable. ${ }^{2,7-9}$ Daruwalla JS recommended operative intervention for midshaft and proximal forearm fractures with angulations $>10^{\circ}$ because of limited remodeling potential in these areas of the bone. ${ }^{10}$ Residual deformities can affect forearm motion. Matthews LS et al showed in a cadaveric study that forearm angular deformities of $10^{\circ}$ will not result in significant loss of forearm pro/supination but that angulation of $20^{\circ}$ will restrict forearm rotation approximately $30 \% .{ }^{11}$ Another cadaveric study by Tarr RR et al demonstrated that fracture angulation between five and ten degrees at mid shaft of forearm can lead to pronation deficit of $5 \%$ to $27 \%$ of normal. ${ }^{12}$ Given the potential failure of non operative management $(1.5 \%$ to $31 \%)$ and the importance of minimizing angular deformity to preserve normal forearm rotation, operative management of pediatric forearm fracture has been increasingly popular. ${ }^{12}$

When indicated, operative fixation of pediatric forearm fractures usually is effective regardless of the method of fixation. ${ }^{2,3,8,11,14}$ Flexible intramedullary nailing is preferred fixation method for pediatric forearm fractures. Most series show good to excellent results using this method. ${ }^{2,3,8,11,14}$ Titanium elastic nails are a popular choice, but they are expensive and not easily available in most of the hospitals in developing countries. Rush pin can be used like titanium nails and their functional outcome is as good as that of Titanium nails as shown in the present study where 47 (94\%) patients had excellent results and is copmarable with other similar study (table 2 ). Due to less malleability of rush pin insertion is difficult than that of titanium nails. In comparision to platings which is more suitable for older children (10-15 years) for accurate anatomic alignment and early unprotected range of motion, intramedullary Rush pins also offer various potential benefits in terms of cosmesis, easy removal of implants after treatment and decreased chances of neurovascualr injuries. ${ }^{9,15}$

Close reduction or open reduction before intramedullary

\section{REFERENCES}

1. Amstrong PF, Jouglin VE, Clarke HM, Greene NE, Swiontkowski MF. Pediatric fracture of forearm, wrist and hand. In Skeletal trauma in children, Philadelphia, Saunders 1998; 161- 257.

2. Shoemaker S. Comstock C. Mubarak S, Wenger DR, Chambers HG. Intramedullary Kirschner wire fixation of open or unstable forearm fractures in children. J Pediatr Orthop 1999; 19:329-37.

3. Fynn JM, Jones KJ,Garner MR, Goebel J. Eleven years experience in operative management of pediatric forearm fracture. I J Pediatr orthop 2010; 30: 313- 19.

4. Schmittenbecher PP. State-of-the-art treatment of forearm shaft fractures. Injury 2005; 36(suppl 1):A25-34.

5. Pinriguez Merchan EC. Pediatric fractures of forearm. Clinical Orthopedics Related Research 2005; 432: 65-72.

6. Wilkins KE. Operative management of children's fractures: is it a sign of impetuousness or do the children really benefit? J Pediatr Orthop 1998; 18: 1-3. nailing yield similar functional results, with similar complication profile in pediatric diaphyseal fracture..$^{13}$ In the present study, 19 patients required open reduction because of soft tissue interposition or difficult cannualtion because of callus formation. Though we did not compare the results of open Vs close technique but we included both techniques, where results are good to excellent.

The complications in the present study are comparable to other various studies . Yalcinkaya $M$ et al reporetd complications rate ranged from $4-38 \%$ in patients treated with intramedullary nailing and Flynn JM et al showed that the overall complication rate in patients undergoing intramedullary nailing was $14.6 \% .^{3,13}$ The most common complication occurring in their series were delayed union, compartment syndrome, infection, skin irritation by hard ware and pin back out. In our series, minor complications were noted in eight (16\%) cases. No nonunions or malunions occurred. There were no deep infections noted.

\section{CONCLUSION}

When indicated, intramedullary rush pin fixation for displaced and unstable pediatric forearm fractures yield good to ecxellent resluts as a minimally invasive procedure with minimal skin scar. Complications found were minor without effecting final outcome and comparbale with other studies. Rush pins are easily available and affordable to most of the patients in developing countries.

Retrospective and non comparative nature of the present study is a limitation of our study. Similar study with a nonoperative control group or a comparative study with another operative technique of longer duration follow up would be ideal for definite conclusion.

7. Teoh KH, Chee YH, Shortt N, Wilkinson G, Porter DE. An age and sex matched comparative study on both bone diaphyseal pediatric forearm fracture. J Child Orthop 2009; 3: 367- 73.

8. Richter D, Ostermann P, Ekkernkamp A, Muhr G, Hahn MP. Elastic intramedullary nailing: a minimally invasive concept in the treatment of unstable forearm fractures in children. J Pediatr Orthop 1998; 18:457-61.

9. Smith VA, Goodman HJ, Strong water A, Smith B. Treatment of Pediatric Both bone forearm fractures: a comparision of operative techniques. J Pediatr Orthop 2005; 25(3): 309- 13.

10. Daruwalla JS. A study of radioulnar movements following fractures of the forearm in children. Clin Orthop Relat Res 1979; 139:114-20.

11. Mathews LS, Kaufer H, Garner DF, Sonstegard DA. The effect on supination- pronation of angular mal-alignment of fractures of both bones of the forearm. J. Bone joint Surgery Am 1982; 64: 14-7. 
12. Tarr RR, Garfinkel Al, Sarmiento A. The effects of angular and rotational deformities of both bones of the forearm: an in vitro study. J Bone Joint Surg Am 1984;66:65-70.

13. Yalcinkaya M, Dogan A, Ozkaya V, Sokucu S, Uzumcugil O, Kabukcuoglu Y. Clinical results of intramedullary nailing following closed or mini open reduction in pediatric unstable diaphyseal forearm fractures. Acta Orthop Traumatol Turc 2010; 44 (1): 7-13.
14. Garg NK, Bhallal MS, Malek IA, Webster RA, Bruce CE. Use of elastic stable intramedullary nailing for treating unstable forearm fracture in children. J Trauma 2008; 65: 109-15.

15. Fernandez FF, Egenolf M, Cansten C, Holz F, Schneider S, Wentzensen A. Unstable diaphyseal fracture of Both Bones of the forearm in children. Plate fixation Vs Intramedullary nailing. Injury 2005; 36 (10): 1210-6. 